\section{Determining Nutrient Diagnostic Norms for Greenhouse Roses}

\author{
Johnn Jairo Franco Hermida \\ Departamento Técnico, GR. Chía S.A., Centro Empresarial Chía-Oficina \\ 314, Chía, Colombia
}

Martha Cecilia Henao Toro

Facultad de Agronomía, Carrera 45 No. 26-85, Edificio Uriel Gutiérrez, Universidad Nacional, Bogotá D.C., Colombia

\author{
Miguel Guzmán \\ Departamento de Agronomía, Universidad de Almería, Crta. Sacramento s/n, \\ La Cañada de San Urbano, 04120 Almería, Spain
}

\author{
Raul I. Cabrera ${ }^{1}$ \\ Department of Horticultural Sciences, Texas A\&M AgriLife Research, 1619 \\ Garner Field Road, Uvalde, TX 78801
}

Additional index words. CND, cut flowers, DRIS, fertilization management, nutrient diagnosis, Rosa spp.

\begin{abstract}
Greenhouse-grown cut roses are an economically important and intensive horticultural cropping system receiving large water, fertilizer, agrochemicals, and labor inputs. This study was conducted to establish and validate norms for the nutrient diagnosis techniques Diagnosis and Recommendation Integrated System (DRIS) and Compositional Nutrient Diagnosis (CND) for cut roses (Rosa spp. L.) growing on soil beds within greenhouses in the Bogotá Plateau, Colombia. Information used in this study was obtained from a database of plant tissue and soil analyses, including 1914 foliar analyses of different rose cultivars grafted on the rootstock $R . \times$ 'Natal Briar'. Theoretical validation proved that the generated norms are suitable for crop nutrient status diagnosis, allowing for the correlation of nutrient balance indices with crop flower productivities across a range of cultivars and plant ages. Analysis of the results provided by both DRIS and CND procedures indicated that element relations associated with nitrogen, phosphorous, magnesium, manganese, and boron had a higher influence on the nutritional balance and productivity of roses growing under the conditions of the studied region. In addition, it was preliminarily determined that the use of these diagnostic norms could be extended to rose crops growing under other, and different, rootstocks, production and environmental conditions, and management.
\end{abstract}

Cut roses are one of the most economically important and intensively managed floriculture greenhouse crops (de Hoog, 2001). Colombia, the world's second largest cut flower exporter, uses $33 \%$ of its total flower production area (6800 ha) for greenhouse rose production, whose flowers accounted for $33 \%$ of the total cut flowers exported in 2010, mostly to the United States (Asocolflores, 2012).

Compared with most agronomic and horticultural crops, greenhouse roses have unparalleled fertilizer applications and could annually receive, through continuous fertigation, $5000 \mathrm{~kg} \cdot \mathrm{ha}^{-1}$ or more of nitrogen with other nutrients also applied, proportionally, in high amounts (Cabrera, 2000, 2003, 2006).

Received for publication 15 Mar. 2013. Accepted for publication 11 Sept. 2013.

We thank G.R. Chía S.A., Juan Carlos González, Daniel Ortega Rey, Juan Gonzalo Piedrahita, Andrés Castañeda, and Mauricio Sarmiento for their valuable help and support throughout this project.

${ }^{1}$ To whom reprint requests should be addressed; e-mail r-cabrera@tamu.edu.
Although the maintenance of a vigorous and sustained year-round productivity in greenhouse roses is associated with high nutrient requirements, it has been shown that these fertilizer applications significantly exceed crop demand, resulting in massive losses to leaching and runoff. Unfortunately, the use of foliar and soil analyses using critical nutrient concentration ranges that were not developed on flower or biomass productivity considerations, but rather on subjective foliage aesthetics (Cabrera, 2000), have largely contributed to the overuse of fertilizers in cut rose production.

The diagnosis of the nutrient status of horticultural crops is important to maximize productivity and optimize fertilizer use while minimizing production costs and environmental impact (Ramos-Miras et al., 2011). The most common method used for crop nutrient status and diagnosis is the critical nutrient range, whereby the nutrient concentration value from plant tissue or a soil sample is compared with a reference level (Lucena, 1997; Marschner, 1995). One of the inconveniences of this method is the difficulty in determining which elements are most limiting and, when adjusting their application, will produce a significant response in yield or quality (Guzmán and Sánchez, 2003; Hartz et al., 2007). A solution to this challenge is the use of other diagnosis techniques such as DRIS (Beaufils, 1973) and CND (Parent and Dafir, 1992).

The DRIS method was originally proposed by Beaufils (1973) and it is based primarily on 1) the relationship between the total contents of nutrients in plant tissues [e.g., calcium $(\mathrm{Ca}) /$ magnesium $(\mathrm{Mg})]$ are better indicators than individual total values (e.g., \% Ca); 2) some of these relationships are more important or significant than others in the crop yield; 3 ) the nutritional status of the crop is not a limiting factor when the values of significant relationships are "close" to the values of the standards (benchmarks taken from an ideal population); 4) then the balance index for each nutrient can be calculated as the average deviation between the value of the relationship in the sample and the standard. Therefore, the ideal value for the index of balance must be zero. Significance is obtained through statistical tests ( $F$-test, $t$ test) between the relationships of the elements present in the population of high yield and the same in the population of poor performance. The CND method was proposed by Parent and Dafir (1992) and is based on the same principles of DRIS, but its mathematical development is more elaborated and it has greater statistical rigor. In addition, CND considers not only the ratios between elements, but also the proportions between an element and all others (Lucena, 1997; Magallanes et al., 2006).

In more concise terms, the DRIS and CND systems are based on the comparison of the results of plant tissue analysis with a norm based on nutrient ratios. The results are presented as indices that quantify, in a hierarchical order, the effect of each nutrient on the crop nutritional balance. The index values could be positive (indicating a possible nutrient excess) or negative (i.e., nutrient deficiency) and are presented on a continuous scale. Several studies have demonstrated the advantages of these methods in the prediction of nutritional imbalances that significantly affect crop productivity, even when the plants have individual nutrient levels within the conventional sufficiency (optimum) ranges and do not show any visual symptoms of deficiency (Fageria, 2001; García et al., 2006; Huang et al., 2012; Lucena, 1997; Martín et al., 2007; Mourão and Azevedo, 2003).

The objectives of this work were to establish the DRIS and CND diagnosis norms for greenhouse cut roses grown under Colombian conditions and to validate the functionality of these norms at a theoretical level.

\section{Materials and Methods}

\section{Crop cultural conditions}

The research area included 20 floriculture farms located on the Bogotá Plateau, Departamento de Cundinamarca, Colombia. The studied rose crops had plants with ages ranging from 1 to 7 years and plant densities 
of 6.7 to 7.0 plants $/ \mathrm{m}^{2}$. Plants were grown in organically amended soil beds under plastic greenhouses and were fertigated through drip irrigation. The nutrient solution formulations used in these crops had the following composition (in $\mathrm{mg} \cdot \mathrm{L}^{-1}$ ): 140 to 180 nitrogen $(\mathrm{N})$, 30 to 40 phosphorus (P), 150 to 200 potassium (K), 100 to $150 \mathrm{Ca}, 40$ to $70 \mathrm{Mg}, 0.5$ to 1.0 manganese $(\mathrm{Mn}), 0.5$ to 2.0 iron $(\mathrm{Fe}), 0.1$ to 0.5 copper $(\mathrm{Cu}), 0.2$ to 0.6 zinc $(\mathrm{Zn})$, and 0.5 to 1.0 boron (B). The average daily temperature on the study area is $14^{\circ} \mathrm{C}$ and annual rainfall is $700 \mathrm{~mm}$ [Instituto Geográfico Agustín Codazzi (IGAC), 2000].

The common soil textures in the study area range from loam to clay loam (IGAC, 2000). A total of 9555 soil samples were collected in the research area during the 2003-07 period and chemically analyzed. The soil chemical analyses were done at the Laboratorio de Suelos, GRChía S.A. using standard methodology (as per IGAC, 1990), and which included $\mathrm{pH}$ in 1:1 soil:distilled water slurries; electrical conductivity (EC) in saturated paste extracts (with an EC meter); organic matter by Walkley-Black method; cation exchange capacity in ammonium acetate ( $\mathrm{pH} 7$ ) extracts; $\mathrm{NH}_{4}-\mathrm{N}$ and $\mathrm{NO}_{3}-\mathrm{N}$ by colorimetry in $\mathrm{KCl}$ extracts; $\mathrm{P}$ by the Olsen method; major cations (K, $\mathrm{Ca}, \mathrm{Mg}$, sodium) by atomic absorption spectroscopy in ammonium acetate extracts; sulfur (S) by flame photometry in calcium phosphate $(0.008 \mathrm{M})$ extracts; metallic micronutrients ( $\mathrm{Fe}, \mathrm{Mn}$, $\mathrm{Cu}, \mathrm{Zn}$ ) by atomic absorption spectroscopy in DTPA ( $\mathrm{pH}$ 7.3) extracts; and B by colorimetry in hot water extracts.

\section{Foliar analysis and flower productivity database}

The database included 1914 foliar analysis made between Jan. 2005 to Dec. 2007 with the data representing 264 zones inside the Bogotá plateau. Leaf samples were taken from different rose cultivars grafted on the rootstock $R . \times$ 'Natal Briar' and collected from recently matured leaves, being the fourth or fifth five-leaflet leaf beneath flower buds beginning to show color (sepals reflexing and revealing petal color, the onset of flower opening). The samples were analyzed (Laboratorio de Suelos, GRChía S.A.) with the following methodologies: dry ashing and determination by atomic absorption spectroscopy for $\mathrm{Ca}, \mathrm{Mg}, \mathrm{K}, \mathrm{Fe}, \mathrm{Cu}, \mathrm{Mn}$, and $\mathrm{Zn}$ and colorimetric determination for $\mathrm{P}$ and $\mathrm{B}$. Nitrogen and $\mathrm{S}$ were determined by acid (wet) digestion and micro-Kjeldahl, and turbidometric procedures, respectively (IGAC, 1990).

The perennial nature of the rose crop and its recurrent flowering characteristics allow for cyclic flower production management through pruning practices (Cabrera, 2000; Cabrera and Perdomo, 2003), and under Colombian climatic and cultural conditions, these cycles average 12 weeks. Based on previous rose nutrition and productivity studies in roses (Cabrera, 2000, 2002, 2003), for this study, the productivity associated to each foliar analysis was the sum of the weekly flower production per $\mathrm{m}^{2}$ for the 12 weeks after the leaf sampling date. The annual productivity index (flowers $/ \mathrm{m}^{2} /$ year) is the productivity of 12 weeks multiplied by 4.33 (52/ 12 , weeks of the year/considered weeks).

The database with information on foliar nutrient content and associated flower productivity consisted of four data sets. The first, containing 1690 foliar analyses, was used to obtain DRIS and CND norms and henceforth will be known as the "Source" data set. The second data set, called "Cultivars," had 191 foliar analyses and flower productivity data taken from 39 different cultivars growing within a single location but from different greenhouses with plants ranging in age between 1 and 7 years. To diminish the impact of inherently more productive cultivars in this data set, an adimensional value of relative flower productivity was obtained for each cultivar, assigning an arbitrary value of 100 to the sample with greater productivity within each variety and using it to calculate the proportional values to the rest. A third data set, "Charlotte," had 33 foliar analyses from a single cultivar, Charlotte, taken from a single location but from different greenhouses with plants aged 3 to 5 years. The last data set, "Nitrogen" (with 96 foliar analyses), was obtained from an experiment on $\mathrm{N}$ fertilization effects on rose productivity (Cabrera, 2000). The data sets "Cultivars," "Charlotte," and "Nitrogen" were used in the theoretical validation of the diagnostic norms generated from the source (primary) data set.

\section{DRIS norms}

Selecting a high-yield population. A flower production threshold of 130 flowers $/ \mathrm{m}^{2} /$ year was selected based on the upper limits of flower yield expectations for the region.

Establishment of Diagnosis and Recommendation Integrated System norms. A determining aspect in the establishment of suitable norms of diagnosis is the use of a database composed of a large number of representative samples (Mourão, 2004), which in the present study is met by extensive sampling over a broad number of regions and plant materials (cultivars, plant ages, etc.). All the possible ratios (direct and inverse relations) between elements were calculated, including their basic statistics. According to Walworth and Sumner (1987), it is possible to use relations that include the product of two elements when one of them increases its value, and the other decreases, as the tissues age; this procedure is useful when the analyzed plant tissues are not uniform with respect to age. The use of ratios based on the multiplication product of two elements was not considered in the present study because the analyses were made in the same leaves and the same phenological crop stage.

Only one of the two possible combination ratios for a pair of elements was selected (direct or inverse). The first selection criterion was the $F$-test for differences between variances (Beaufils, 1973) and when none of the two combinations had significant differences, a $t$ test of mean differences was applied (Jones, 1981). If these procedures did not yield significant differences, the nutrient ratio with the highest $F$-test value was chosen (Wadt, 1999).

Tissue concentrations for $\mathrm{N}, \mathrm{P}, \mathrm{K}, \mathrm{Ca}, \mathrm{Mg}$, and $\mathrm{S}$ were expressed as percentages of dry matter and the micronutrients in $\mathrm{mg} \cdot \mathrm{kg}^{-1}$. In the ratios involving elements expressed in different units, the elements expressed in percentages were multiplied $\times 100$ to obtain easier to handle numbers, with less decimal places, minimizing the yielding of very low or high variances (Arboleda et al., 1988). The functions for the elements and DRIS indices were determined according to the methodology of Beaufils (1973).

\section{Compositional Nutrient Diagnosis norms}

Yield population separation. This was accomplished following the steps proposed by Khiari et al. (2001a) as follows:

1. Plant flower productivities and their respective foliar analyses in the source data set were arranged in decreasing order.

2. Row-centered log ratios of the nutrient proportions $\left(\mathrm{CND} \mathrm{V}_{\mathrm{x}}\right)$ were calculated using the equation:

$$
\begin{gathered}
V_{\mathrm{N}}=\ln \left(\frac{\mathrm{N}}{G}\right), \quad V_{\mathrm{P}}=\ln \left(\frac{\mathrm{P}}{G}\right), \\
V_{K}=\ln \left(\frac{\mathrm{K}}{G}\right), \ldots, \quad V_{R_{d}}=\ln \left(\frac{R_{d}}{G}\right),
\end{gathered}
$$

where:

$$
G=\left(\mathrm{N} \times \mathrm{P} \times \mathrm{K} \times \mathrm{S} \times \mathrm{Ca} \times \ldots \times R_{\mathrm{d}}\right)^{\frac{1}{d+1}}
$$

and where $d$ is the dimensional nutrient arrangement (number of nutrient considered in the analysis) and $R_{d}$ is the filling value between $100 \%$ and the sum of $d$ nutrient proportions computed as follows:

$$
R_{d}=100-(N+P+K+\ldots)
$$

3. The iterative procedure of Cate-Nelson (Nelson and Anderson, 1977) was applied to divide the source data set into two populations: low and high productivity.

4. For the two populations obtained in each iteration, the $\mathrm{F}$ for component $\mathrm{X} f_{i}\left(V_{x}\right)$ was computed using the expression:

$$
\begin{aligned}
& f_{i}\left(V_{X}\right) \\
& \quad=\frac{\text { Variance of } V_{X} \text { of } n_{1} \text { observations }}{\text { Variance of } V_{X} \text { of } n_{2} \text { observations }}
\end{aligned}
$$

5. Thereafter, the cumulative $F$ function $\left(\mathrm{F}_{\mathrm{i}}^{\mathrm{c}}\left[\mathrm{V}_{\mathrm{X}}\right]\right)$ was calculated:

$$
F_{i}^{C}\left(V_{x}\right)=\frac{\sum_{i=1}^{n_{i}-1} f_{i}\left(V_{x}\right)}{\sum_{i=1}^{n-3} f_{i}\left(V_{x}\right)} \times 100
$$

6. The cumulative functions for each nutrient were related to productivity $(\mathrm{Y})$ according to the cubic expression: 


$$
F_{i}^{C}\left(V_{x}\right)=a Y^{3}+b Y^{2}+c Y+d
$$

7. The inflection point, where the model shows a change in concavity and is the value of productivity $(\mathrm{Y})$ that divides the population in low and high yield, was obtained by the solution of the second derivative of $\left(\mathrm{F}_{\mathrm{i}}^{\mathrm{c}}\left[\mathrm{V}_{\mathrm{X}}\right]\right)$ :

$$
Y=\frac{-b}{3 a}
$$

The flower productivity that separated the source data set into two populations was obtained by selecting the greater productivity of the different resulting values (one for each element) from this last equation.

Establishment of CND norms. The CND method determines the norms as the average and SD of CND $V_{x}$ values for the highyielding population. The probability that an observation corresponded to a low productivity value was obtained by calculating the proportion of the number of observations of the low-yielding population over the total number of observations. The critical value for $\mathrm{CND} r^{2}$ (CND nutrient imbalance index) was obtained with the $\chi^{2}$ probability function with $13 \mathrm{df}(\mathrm{d}+1)$ corresponding to that probability.

Optimum ranges for CND indices for each element and CND $r^{2}$ were obtained by the method proposed by Khiari et al. (2001b, 2001c). This applies the iterative method of Cate-Nelson (Nelson and Anderson, 1977) to CND indices obtained from a population different from the one used to establish the norms. In this case, the secondary data set, "Cultivars," was selected as a result of its number of observations and also the fact that it was constituted of data from a large number of cultivars as with the source data set used to generate the norms.

Theoretical validation of DRIS and CND norms. The validation of the norms was based on the premise that there must be a significant correlation between (flower) productivity and the nutrient balance indices, suggesting that the norms are well chosen and can differentiate samples whose nutrient imbalances are affecting yield (Mourão, 2004). As mentioned previously, the data sets "Charlotte," "Cultivars," and "Nitrogen," not considered in the establishment of the norms, were used in the theoretical validation procedures. The statistics of the data sets are shown in Table 1. Both DRIS and CND methodologies were applied to each data set, and correlation analyses were used to compare the resulting nutrient balance indices of each methodology with their respective flower productivities.

\section{Results and Discussion}

\section{Soil analyses}

The 9555 soil samples collected in the study area during the 2003-07 period generated the following chemical properties averages: $\mathrm{pH}$ 6.4, EC $2.1 \mathrm{dS} \cdot \mathrm{m}^{-1}$, organic matter $8.5 \%$, cation exchange capacity $30.3 \mathrm{cmolc} \cdot \mathrm{kg}^{-1}$, and nutrient contents of (in $\mathrm{mg} \cdot \mathrm{kg}^{-1}$ ): 32 $\mathrm{NH}_{4}-\mathrm{N}, 158 \mathrm{NO}_{3}-\mathrm{N}, 207 \mathrm{P}, 983 \mathrm{~K}, 4468$ $\mathrm{Ca}, 837 \mathrm{Mg}, 257 \mathrm{~S}, 280$ sodium, $138 \mathrm{Fe}$, $15 \mathrm{Mn}, 18 \mathrm{Zn}, 7.4 \mathrm{Cu}$, and $2.8 \mathrm{~B}$.

\section{DRIS norms}

Separation of populations. The descriptive statistics of the elements considered for the high- and low-yielding populations are shown in Table 1. The average nutrient values for the high-yielding population do not differ from the optimum ranges reported for roses (Cabrera, 2003, Mills and Jones, 1996; Ortega, 1997; White, 1987), except for $\mathrm{Zn}$, which is slightly higher. The values for $\mathrm{Mn}, \mathrm{Fe}, \mathrm{Cu}, \mathrm{B}$, and $\mathrm{Zn}$ reported by different authors denote a rather wide range, which concurs with the high cvs observed for these elements in the studied populations (Table 1).

Mean comparison tests ( $t$ test) and variance $(F$-test, with $283 \mathrm{df}$ in the numerator and $1405 \mathrm{df}$ in the denominator) were applied to

Table 1. Statistics for the high- and low-yielding populations and data sets used in the establishment and theoretical validation of nutrient diagnostic norms for

\begin{tabular}{|c|c|c|c|c|c|c|c|c|c|c|c|c|c|}
\hline Statistical parameter $^{y}$ & $\operatorname{Pn}^{x}$ & Pn Rel. ${ }^{x}$ & $\mathrm{~N}^{\mathrm{w}}$ & $\mathrm{P}$ & $\mathrm{K}$ & $\mathrm{Ca}$ & $\mathrm{Mg}$ & $\mathrm{S}$ & $\mathrm{Fe}$ & $\mathrm{Mn}$ & $\mathrm{Zn}$ & $\mathrm{Cu}$ & B \\
\hline \multicolumn{14}{|c|}{ High-yielding population data set } \\
\hline Median & 141.4 & - & 3.80 & 0.28 & 2.01 & 1.47 & 0.29 & 0.36 & 83.6 & 128 & 53 & 7.4 & 67 \\
\hline CV $(\%)$ & 9.0 & - & 11.8 & 16.7 & 21.9 & 26.3 & 19.6 & 20.9 & 34.0 & 45 & 54 & 55.1 & 26 \\
\hline $\mathrm{n}$ & 284 & - & 284 & 284 & 284 & 284 & 284 & 284 & 284 & 284 & 284 & 284 & 284 \\
\hline \multicolumn{14}{|c|}{ Low-yielding population data set } \\
\hline Mean & 95.4 & - & 3.76 & 0.29 & 2.00 & 1.50 & 0.31 & 0.37 & 87.2 & 110 & 51 & 7.7 & 70 \\
\hline $\mathrm{S}$ & 412.0 & - & 0.207 & 0.003 & 0.108 & 0.212 & 0.008 & 0.009 & 1845 & 3421 & 957 & 17.3 & 414 \\
\hline $\mathrm{n}$ & 1406 & - & 1406 & 1406 & 1406 & 1406 & 1406 & 1406 & 1406 & 1406 & 1406 & 1406 & 1406 \\
\hline \multicolumn{14}{|l|}{ Cultivar data set } \\
\hline Mean & 106.3 & 83.1 & 4.00 & 0.31 & 2.03 & 1.97 & 0.36 & 0.44 & 94 & 112 & 53 & 7.2 & 79 \\
\hline Median & 108.8 & 82.9 & 4.00 & 0.31 & 1.98 & 1.89 & 0.35 & 0.44 & 87 & 101 & 47 & 6.6 & 78 \\
\hline CV $(\%)$ & 17.6 & 16.8 & 11.1 & 12.3 & 16.3 & 23.5 & 20.8 & 17.5 & 29 & 49 & 42 & 40.8 & 17.8 \\
\hline SD & 18.7 & 13.9 & 0.45 & 0.04 & 0.33 & 0.46 & 0.08 & 0.08 & 27 & 55 & 22 & 2.9 & 14 \\
\hline SD & 18.6 & - & 0.36 & 0.04 & 0.24 & 0.24 & 0.04 & 0.07 & 19.3 & 60.5 & 66.4 & 4.4 & 11.5 \\
\hline $\mathrm{n}$ & 33 & - & 33 & 33 & 33 & 33 & 33 & 33 & 33 & 33 & 33 & 33 & 33 \\
\hline \multicolumn{14}{|l|}{ Nitrogen data set } \\
\hline Mean & - & 75.2 & 3.00 & 0.34 & 2.63 & 0.84 & 0.25 & 0.34 & 70 & 120 & 48 & 18.2 & 83 \\
\hline Median & - & 83.3 & 3.10 & 0.33 & 2.63 & 0.82 & 0.24 & 0.33 & 70 & 118 & 47 & 18.8 & 79 \\
\hline CV $(\%)$ & - & 27.2 & 19.5 & 18.4 & 13.7 & 16.6 & 17.9 & 13.9 & 18.4 & 26.1 & 46.2 & 33.3 & 31.6 \\
\hline $\mathrm{SD}$ & - & 20.4 & 0.59 & 0.06 & 0.36 & 0.14 & 0.04 & 0.05 & 12.9 & 31.29 & 22.2 & 6.05 & 26.3 \\
\hline $\mathrm{n}$ & - & 36 & 36 & 36 & 36 & 36 & 36 & 36 & 36 & 36 & 36 & 36 & 36 \\
\hline \multicolumn{14}{|c|}{ Recommended values for foliar nutrient concentrations for Rosa spp. } \\
\hline Cabrera, 2003 & & & $3.0-4.0$ & $0.2-0.4$ & $1.5-2.5$ & $1.0-2.0$ & $0.2-0.4$ & $0.15-0.25$ & $50-150$ & $50-200$ & $20-50$ & $3-15$ & $30-80$ \\
\hline Mills and Jones, 195 & & & $2.8-3.6$ & $0.24-0.33$ & $1.6-2.2$ & $1.0-1.7$ & $0.3-0.43$ & - & $75-384$ & $91-179$ & $20-49$ & $5-8$ & 24-63 \\
\hline Ortega, 1997 & & & $3.0-5.0$ & $0.2-0.3$ & $1.6-2.5$ & $1.0-2.0$ & $0.3-0.4$ & - & $80-150$ & $100-300$ & $15-50$ & $7-17$ & $40-80$ \\
\hline White, 1987 & & & $3.0-5.0$ & $0.2-0.3$ & $1.8-3.0$ & $1.0-1.5$ & $0.25-0.35$ & - & $50-150$ & $30-250$ & $15-50$ & $5-15$ & $30-60$ \\
\hline
\end{tabular}
Rosa spp. and recommended rose leaf nutrient concentrations from the literature. ${ }^{\mathrm{z}}$

${ }^{\mathrm{z}}$ See text for specific information on each data set.

${ }^{y} \mathrm{CV}(\%) ; \mathrm{S}=$ variance; $\mathrm{n}=$ sample number. The high-yielding population was selected for flower productivities $130 \mathrm{flowers} / \mathrm{m}^{2} /$ year or greater.

${ }^{\mathrm{x}} \mathrm{Pn}=$ flower productivity (flowers $/ \mathrm{m}^{2} /$ year); Pn Rel. = relative flower productivity.

${ }^{\mathrm{w}}$ Macronutrients expressed in percent dry weight and micronutrients in $\mathrm{mg} \cdot \mathrm{kg}^{-1}$ dry weight. 
the nutrient concentrations in the high- and low-yielding populations (Table 2). It was observed that in seven of the 11 studied nutrients, the variance is significantly smaller in the high-yielding population $(\alpha=0.1)$, in agreement with the principles of both the DRIS (Beaufils, 1973) and CND systems (Parent and Dafir, 1992) and is a good indication that the resulting norms are reliable. Significant differences between means were found in four elements $(\alpha=0.1)$, where $P$ and $\mathrm{B}$ concentrations were lower in the highyielding population, and $\mathrm{N}$ and $\mathrm{Mn}$ were higher for this population (Table 2). It should be noted that soil $\mathrm{P}$ levels in the flowergrowing regions in Colombia are very high (averaging $207 \mathrm{mg} \cdot \mathrm{kg}^{-1}$ on the evaluated 9555 soil samples) and the application of fairly high $\mathrm{P}$ and $\mathrm{B}$ concentrations, and other elements, in the fertigation formulas are a common occurrence (Cabrera, 2003). The accumulation of high $\mathrm{B}$ concentrations in leaf tissues leads to toxicity problems and flower yield reductions (Cabrera, 2003; White, 1987), and the strong antagonism between $\mathrm{P}$ and some micronutrients can reduce yields (Fageria, 2001; Marschner, 1995). With respect to rose leaf $\mathrm{N}$, moderate increases in its concentration within the $2.5 \%$ to $3 \%$ (by dry weight) range have been shown to increase flower and biomass yields in soilless-grown roses growing in northern latitudes and low elevations (Cabrera, 2000). In the equatorial latitudes and mountain range elevations found in the Bogota Plateau, certainly a higher leaf $\mathrm{N}$ concentration range was found in its soilgrown roses, and yet significantly higher $\mathrm{N}$ concentrations were observed in the highyield population plants. Regarding $\mathrm{Mn}$, its concentrations in the soils of flower farms in Colombia are typically very low (averaging $15 \mathrm{mg} \cdot \mathrm{kg}^{-1}$ ) with reports of its deficiency being a common occurrence in these crops (Ortega, 1997).

Relations between elements. The means and CVS in the relations obtained between elements for the high-yielding population, and the statistical tests between this and the

Table 2. Results of F-test and $t$ test applied to the variances and means, respectively, of the nutrient concentrations in leaf tissues of highand low-yielding populations of Rosa spp. grafted on $R . \times$ 'Natal Briar'.

\begin{tabular}{lcc}
\hline Nutrient & $F$ test $\left(\mathrm{S}_{\mathrm{a}}<\mathrm{S}_{\mathrm{b}}\right)^{\mathrm{z}}$ & $t$ test $\left(\mu_{\mathrm{a}}<>\mu_{\mathrm{b}}\right)^{\mathrm{y}}$ \\
\hline $\mathrm{N}$ & 1.00 & $0 *$ \\
$\mathrm{P}$ & $1.29^{* \mathrm{x}}$ & $0.04^{*}$ \\
$\mathrm{~K}$ & 0.54 & 0.32 \\
$\mathrm{Ca}$ & $1.39^{*}$ & 0.5 \\
$\mathrm{Mg}$ & $2.36^{*}$ & 0.14 \\
$\mathrm{~S}$ & $1.38^{*}$ & 0.28 \\
$\mathrm{Fe}$ & $2.00^{*}$ & 0.32 \\
$\mathrm{Mn}$ & 1.04 & $0 *$ \\
$\mathrm{Zn}$ & $1.15^{*}$ & 0.41 \\
$\mathrm{Cu}$ & 0.85 & 0.13 \\
$\mathrm{~B}$ & $1.36^{*}$ & $0.07^{*}$ \\
\hline
\end{tabular}

${ }^{{ }^{z}} \mathrm{~S}_{\mathrm{a}}$ and $\mathrm{S}_{\mathrm{b}}=$ variance of the high-yield and lowyielding populations, respectively.

${ }^{\mathrm{y}} \mu_{\mathrm{a}}$ and $\mu_{\mathrm{b}}=$ mean of the high-yield and lowyielding populations, respectively.

${ }^{\mathrm{x}}$ The values followed by $*$ are significant at $\alpha=0.1$. low-yielding population, are shown in Table 3. Of 55 total combinations, only five groups of combinations, $\mathrm{K}-\mathrm{Ca}, 100 \mathrm{~K}-\mathrm{Cu}, 100 \mathrm{~K}-\mathrm{B}$, $100 \mathrm{~S}-\mathrm{Cu}, \mathrm{Zn}-\mathrm{Cu}$, did not have significant differences $(\alpha=0.1)$ in means or variances. In the remaining combinations, there was a significant difference in at least one of these parameters. In general the CVs were found high in the relations that contain $\mathrm{Mn}, \mathrm{Zn}$, or $\mathrm{Cu}$ (Table 3), an aspect likely inherited from the $\mathrm{CV}$ observed in the database (Table 1). High cVs are common in results from DRIS investigations made by others (García et al.,
2005; Huang et al., 2012; Jones, 1981; Magallanes et al., 2004; Martín et al., 2007; Mourão and Azevedo, 2003).

Norms. Of all the possible elemental nutrient ratios (direct and inverse relations) in the high-yielding rose population, 55 were selected as DRIS norms (Table 3). When comparing these norms with those from the low-yielding population, it was observed that 37 of these selected norms had a significantly smaller variance, 20 had significant differences in their means, nine had both characteristics, and only five did not have any

Table 3. Ratios and Diagnosis and Recommendation Integrated System norms selected for Rose spp. grafted on $R . \times$ 'Natal Briar' obtained from a population with yields 130 flowers $/ \mathrm{m}^{2} /$ year or greater.

\begin{tabular}{|c|c|c|c|c|}
\hline Ratios $^{z}$ & Mean & $\mathrm{CV}(\%)$ & $F$ test $\left(\mathrm{S}_{\mathrm{b}} / \mathrm{S}_{\mathrm{a}}\right)^{\mathrm{y}}$ & $t$ test $\left(\mu_{\mathrm{a}}<\mu_{\mathrm{b}}\right)^{\mathrm{x}}$ \\
\hline$\overline{\mathrm{P} / \mathrm{N}}$ & 0.074 & 17.08 & $1.19 * \mathrm{w}$ & 0.2 \\
\hline $\mathrm{K} / \mathrm{N}$ & 0.53 & 21.65 & 0.7 & $0.01 *$ \\
\hline $\mathrm{Ca} / \mathrm{N}$ & 0.39 & 26.79 & $1.41 *$ & 0.8 \\
\hline $\mathrm{Mg} / \mathrm{N}$ & 0.078 & 19.27 & $2.77 *$ & $0.002 *$ \\
\hline $\mathrm{N} / \mathrm{S}$ & 10.48 & 20.51 & $1.18^{*}$ & $0.02 *$ \\
\hline $\mathrm{Fe} / 100 \mathrm{~N}$ & 3.45 & 37.47 & $1.58 *$ & 0.3 \\
\hline $\mathrm{Mn} / 100 \mathrm{~N}$ & 4.88 & 44.59 & $1.15^{*}$ & $0.04^{*}$ \\
\hline $\mathrm{Zn} / 100 \mathrm{~N}$ & 2.03 & 53.36 & $1.29 *$ & $0.01 *$ \\
\hline $100 \mathrm{~N} / \mathrm{Cu}$ & 59.44 & 65.54 & 0.6 & $0.0006 *$ \\
\hline $\mathrm{B} / 100 \mathrm{~N}$ & 2.62 & 29.23 & $1.15^{*}$ & 0.8 \\
\hline $\mathrm{P} / \mathrm{K}$ & 0.14 & 20.00 & $1.15^{*}$ & 0.5 \\
\hline $\mathrm{P} / \mathrm{Ca}$ & 0.21 & 38.01 & $1.26^{*}$ & 0.8 \\
\hline $\mathrm{Mg} / \mathrm{P}$ & 1.08 & 22.85 & $2.38 *$ & 0.4 \\
\hline $\mathrm{P} / \mathrm{S}$ & 0.77 & 26.16 & $1.38^{*}$ & 0.6 \\
\hline $\mathrm{Fe} / 100 \mathrm{P}$ & 0.25 & 37.37 & $2.53 *$ & $0.06^{*}$ \\
\hline $100 \mathrm{P} / \mathrm{Mn}$ & 0.29 & 69.67 & $1.58 *$ & 0.5 \\
\hline $\mathrm{Zn} / 100 \mathrm{P}$ & 0.15 & 54.00 & $1.3^{*}$ & 0.1 \\
\hline $\mathrm{Cu} / 100 \mathrm{P}$ & 0.022 & 53.67 & 0.9 & $0.01 *$ \\
\hline $\mathrm{B} / 100 \mathrm{P}$ & 0.19 & 31.89 & $1.27 *$ & 0.3 \\
\hline $\mathrm{K} / \mathrm{Ca}$ & 1.46 & 32.15 & 1.1 & 0.2 \\
\hline $\mathrm{Mg} / \mathrm{K}$ & 0.15 & 22.71 & $2.38 *$ & 0.7 \\
\hline $\mathrm{S} / \mathrm{K}$ & 0.19 & 23.18 & $1.57 *$ & $0.002 *$ \\
\hline $100 \mathrm{~K} / \mathrm{Fe}$ & 2.42 & 27.40 & 1.1 & $0.001 *$ \\
\hline $\mathrm{Mn} / 100 \mathrm{~K}$ & 2.61 & 49.14 & 1.0 & $0.08 *$ \\
\hline $\mathrm{Zn} / 100 \mathrm{~K}$ & 1.08 & 59.31 & $1.18^{*}$ & 0.3 \\
\hline $100 \mathrm{~K} / \mathrm{Cu}$ & 31.06 & 62.68 & 0.7 & 0.6 \\
\hline $100 \mathrm{~K} / \mathrm{B}$ & 3.18 & 32.21 & 1.0 & 0.6 \\
\hline $\mathrm{Mg} / \mathrm{Ca}$ & 0.21 & 23.63 & $2.48^{*}$ & 0.2 \\
\hline $\mathrm{S} / \mathrm{Ca}$ & 0.27 & 31.27 & $1.32 *$ & 0.8 \\
\hline $\mathrm{Fe} / 100 \mathrm{Ca}$ & 1.36 & 48.52 & $1.62 *$ & $0.03 *$ \\
\hline $\mathrm{Mn} / 100 \mathrm{Ca}$ & 1.91 & 52.77 & $1.17^{*}$ & 0.6 \\
\hline $\mathrm{Zn} / 100 \mathrm{Ca}$ & 0.81 & 65.79 & $1.16^{*}$ & 0.4 \\
\hline $\mathrm{Cu} / 100 \mathrm{Ca}$ & 0.12 & 66.63 & 1.0 & $0.0002 *$ \\
\hline $\mathrm{B} / 100 \mathrm{Ca}$ & 1.03 & 42.38 & $1.39 *$ & 0.4 \\
\hline $\mathrm{Mg} / \mathrm{S}$ & 0.81 & 22.64 & $2.51 *$ & 0.7 \\
\hline $100 \mathrm{Mg} / \mathrm{Fe}$ & 0.35 & 25.96 & $2.5^{*}$ & 0.7 \\
\hline $\mathrm{Mn} / 100 \mathrm{Mg}$ & 0.38 & 48.16 & $1.28 *$ & 0.2 \\
\hline $\mathrm{Zn} / 100 \mathrm{Mg}$ & 0.16 & 57.37 & $1.54 *$ & 0.9 \\
\hline $100 \mathrm{Mg} / \mathrm{B}$ & 0.47 & 35.9 & $1.5^{*}$ & $0 *$ \\
\hline $\mathrm{Fe} / 100 \mathrm{~S}$ & 0.34 & 42.2 & $1.5^{*}$ & 0.7 \\
\hline $100 \mathrm{~S} / \mathrm{Mn}$ & 0.39 & 68.3 & $1.24 *$ & 0.6 \\
\hline $\mathrm{Zn} / 100 \mathrm{~S}$ & 0.20 & 61.9 & 1.1 & $0.04 *$ \\
\hline $100 \mathrm{~S} / \mathrm{Cu}$ & 5.68 & 55.5 & 0.9 & 0.6 \\
\hline $\mathrm{B} / 100 \mathrm{~S}$ & 0.26 & 35.7 & $1.3^{*}$ & 0.5 \\
\hline $\mathrm{Fe} / \mathrm{Zn}$ & 2.12 & 53.8 & $1.8^{*}$ & 0.3 \\
\hline $\mathrm{Fe} / \mathrm{Cu}$ & 13.41 & 62.2 & 1.0 & $0.04 *$ \\
\hline $\mathrm{B} / \mathrm{Fe}$ & 0.81 & 32.8 & $1.3^{*}$ & 0.9 \\
\hline $\mathrm{Mn} / \mathrm{Zn}$ & 2.85 & 56.6 & 0.7 & $0.03 *$ \\
\hline $\mathrm{Cu} / \mathrm{Mn}$ & 0.086 & 91.6 & $1.5^{*}$ & 0.9 \\
\hline $\mathrm{B} / \mathrm{Mn}$ & 0.71 & 78.0 & 1.1 & $0.06^{*}$ \\
\hline $\mathrm{Cu} / \mathrm{Zn}$ & 0.19 & 66.7 & 1.1 & 0.5 \\
\hline $\mathrm{B} / \mathrm{Zn}$ & 1.59 & 49.3 & $1.2 *$ & $0 *$ \\
\hline $\mathrm{B} / \mathrm{Cu}$ & 10.14 & 52.7 & 1.0 & $0.05^{*}$ \\
\hline
\end{tabular}

${ }^{\mathrm{z}}$ For the calculation of these ratios, macronutrients were expressed in percent of dry weight and micronutrients in $\mathrm{mg} \cdot \mathrm{kg}^{-1}$.

${ }^{\mathrm{y}} \mathrm{S}_{\mathrm{a}}$ and $\mathrm{S}_{\mathrm{b}}=$ variance of the high-yield and low-yielding populations, respectively.

${ }^{\mathrm{x}} \mu_{\mathrm{a}}$ and $\mu_{\mathrm{b}}=$ mean of the high-yield and low-yielding populations, respectively.

whe values followed by $*$ are significant at $\alpha=0.1$. 
significant differences. The observation of a large number of norms with significant differences (in variances and/or means) with respect to the low-yielding population suggests these norms are reliable and furthermore indicate that differences in productivity are likely the result of nutritional imbalances (Jones, 1981; Ruíz and Cajuste, 2002). The CVs in the elemental ratios ranged between $17 \%$ and $91 \%$ with 22 norms presenting a CV greater than $50 \%$. These high $\mathrm{CV}$ values were carried over from the wide variations encountered in the concentrations of some individual elements, for example $\mathrm{Cu}$ and $\mathrm{Mn}$, and their resulting $\mathrm{Cu} / \mathrm{Mn}$ ratio (Table 3 ).

According to Reis and Monnerat (2003), when there is a very low variance in a norm from the high-yielding population (high $F$ values, $>2$ ), and in addition the mean has a small variance (relatively low CV), this leads to the contention that the crop is very responsive to a small change in that balance (norm). In the selected norms (Table 3 ), the ratios of $\mathrm{Mg} / \mathrm{N}, \mathrm{Mg} / \mathrm{P}, \mathrm{Mg} / \mathrm{K}, \mathrm{Mg} / \mathrm{Ca}, \mathrm{Mg} / \mathrm{S}$, $100 \mathrm{Mg} / \mathrm{Fe}$ meet these conditions, which suggests that small changes in the concentrations of $\mathrm{Mg}$ have a highly significant impact on the flower yields of rose plants. Magnesium is hereby identified as a limiting element. Indeed, one of the most common nutrient deficiencies in rose crops in the Bogotá Plateau is $\mathrm{Mg}$, largely attributed to an antagonistic effect of K (Marschner, 1995; Merhaut, 2007), which is very high in the soils from this flowergrowing region, averaging over $900 \mathrm{mg} \cdot \mathrm{kg}^{-1}$ (IGAC, 2000; Ortega, 1997). Given these results, it is contended that nutrient imbalances associated with limiting Mg levels significantly affect rose crop productivity in this region.

\section{CND norms}

Separation of populations. Cumulative F functions were calculated for each element along with their respective coefficients of determination and the inflection point values of each function (Table 4), which in this case represent the critical productivity that separates the high- and low-yielding populations. According to these results, 137 flowers $/ \mathrm{m}^{2} /$ year was the productivity that divides these populations. The number of observations that fulfills this productivity is 203 out of a total of 1690 , representing $12 \%$ of the total population. This flower productivity value is very close to the one arbitrarily chosen for the development of the DRIS norms, 130 flowers/ $\mathrm{m}^{2} /$ year, thus ratifying both its selection and the confidence in the resulting DRIS norms.

This highest inflection point, or maximum flower yield value, separating the two rose populations was associated with $\mathrm{N}$ (Table 4), confirming its importance in the overall nutrition of rose crops (Cabrera, 2000) and its potential to cause nutrient imbalances that can significantly affect flower and biomass productivities (Cabrera, 2006). In the total population used in this study, the variance in $\mathrm{N}$ concentration was smaller in the highyielding subpopulation. Therefore, any sample with $\mathrm{N}$ levels differing from those in the

Table 4. Cumulative $\mathrm{F}$ functions $\mathrm{F}^{\mathrm{c}}\left(\mathrm{V}_{\mathrm{x}}\right)$, derived for selected mineral elements, by Compositional Nutrient Diagnosis methodology, where ' $y$ ' is equal to the value of $F^{c}\left(V_{x}\right)$ and ' $x$ ' is equal to Pn.

\begin{tabular}{llcc}
\hline Nutrient & \multicolumn{1}{c}{ Function $\mathrm{F}^{\mathrm{c}}\left(\mathrm{V}_{\mathrm{x}}\right)$ vs. Pn } & $R^{2}$ & $\mathrm{Y}_{\text {ip }}(-\mathrm{b} / 3 \mathrm{a})^{\mathrm{z}}$ \\
\hline $\mathrm{N}$ & $\mathrm{y}=0.0001 \mathrm{x}^{3}-0.0411 \mathrm{x}^{2}+3.44 \mathrm{x}+19.90$ & 0.9973 & $137^{\mathrm{y}}$ \\
$\mathrm{P}$ & $\mathrm{y}=0.0001 \mathrm{x}^{3}-0.0385 \mathrm{x}^{2}+2.79 \mathrm{x}+41.29$ & 0.9975 & 128 \\
$\mathrm{~K}$ & $\mathrm{y}=0.0001 \mathrm{x}^{3}-0.0371 \mathrm{x}^{2}+2.59 \mathrm{x}+49.00$ & 0.9972 & 124 \\
$\mathrm{Ca}$ & $\mathrm{y}=0.0001 \mathrm{x}^{3}-0.037 \mathrm{x}^{2}+2.51 \mathrm{x}+52.23$ & 0.9966 & 123 \\
$\mathrm{Mg}$ & $\mathrm{y}=0.0001 \mathrm{x}^{3}-0.0336 \mathrm{x}^{2}+2.08 \mathrm{x}+67.27$ & 0.9956 & 112 \\
$\mathrm{~S}$ & $\mathrm{y}=0.0001 \mathrm{x}^{3}-0.0355 \mathrm{x}^{2}+1.97 \mathrm{x}+71.06$ & 0.9962 & 118 \\
$\mathrm{Fe}$ & $\mathrm{y}=0.0001 \mathrm{x}^{3}-0.0394 \mathrm{x}^{2}+2.86 \mathrm{x}+38.98$ & 0.9972 & 131 \\
$\mathrm{Mn}$ & $\mathrm{y}=0.0001 \mathrm{x}^{3}-0.0359 \mathrm{x}^{2}+2.39 \mathrm{x}+54.83$ & 0.9966 & 120 \\
$\mathrm{Zn}$ & $\mathrm{y}=0.0001 \mathrm{x}^{3}-0.0357 \mathrm{x}^{2}+2.44 \mathrm{x}+53.21$ & 0.9976 & 119 \\
$\mathrm{Cu}$ & $\mathrm{y}=0.0001 \mathrm{x}^{3}-0.0387 \mathrm{x}^{2}+2.15 \mathrm{x}+64.07$ & 0.9979 & 129 \\
$\mathrm{~B}$ & $\mathrm{y}=0.0001 \mathrm{x}^{3}-0.0342 \mathrm{x}^{2}+2.09 \mathrm{x}+62.75$ & 0.9976 & 114 \\
$R^{\mathrm{x}}$ & $\mathrm{y}=0.0001 \mathrm{x}^{3}-0.0397 \mathrm{x}^{2}+2.87 \mathrm{x}+39.76$ & 0.9967 & 132 \\
\hline
\end{tabular}

${ }^{\mathrm{z}} \mathrm{Y}_{\text {ip }}=$ inflection points of cumulative variance functions for row-centered log ratios.

${ }^{y}$ Maximum yield cutoff value.

${ }^{\mathrm{x}} R=$ filling value, which includes nutrients not chemically analyzed.

$\mathrm{Pn}=$ flower productivity (flowers $/ \mathrm{m}^{2} /$ year).

norm is less likely to be placed in this highyielding population.

Norms. Elemental concentrations of nutrients in leaf tissues of rose plants with productivities 137 flowers $/ \mathrm{m}^{2} /$ year or greater were used to obtain the CND norms (Table 5). Smaller cvs were observed in the CND norms compared with the DRIS norms. This is because the CND norms are obtained, for each element, from standardized values and in addition they also consider all the elements in a relation (multinutrient ratio; Parent and Dafir, 1992), and not just binary relations (dual ratios) as done in the DRIS system (Silva et al., 2004).

As mentioned previously, $12 \%$ of the population from the source data set constituted the high-yielding subpopulation, therefore producing a probability of $88 \%$ that an observation will be placed in the low-yielding grouping. As previously indicated (in "Materials and Methods"), CND $r^{2}$ values are distributed in a $\chi^{2}$ probability function, in this case with $13 \mathrm{df}$, and with this probability, the critical value of CND $r^{2}$ will be 7.4 (Fig. 1). In theory any sample that surpasses this value has a high probability of being in the lowyielding population.

Optimum ranges for the $\mathrm{CND}\left(\mathrm{I}_{\mathrm{x}}\right)$ indices, for each element, were obtained from the "Cultivars" validation data set (Table 6). The critical index of balance CND $r^{2}$ of 7.1 calculated here is very similar to the value of 7.4 obtained by means of the $\chi^{2}$ distribution (Fig. 1). This result ratifies both the validity of the calculations and the reliability of the CND norms (Khiari et al., 2001b).

Theoretical validation of the DRIS and $C N D$ norms. The relationships between productivity, expressed as flowers $/ \mathrm{m}^{2} /$ year or in relative terms, and the nutritional balance index IBN-DRIS and the index of balance $\mathrm{CND} r^{2}$ were significant $(P<0.001)$ when the DRIS and CND methodologies were applied to the "Cultivars" data set (Fig. 2). These results certainly validate the use of these two diagnostic norms in the prediction of nutrient imbalances in roses grafted on the $R . \times$ 'Natal Briar' rootstock and concur with similar studies in other crops (Khiari et al., 2001c; Magallanes et al., 2006; Mourão and Azevedo, 2003; Sumner, 1979).
Table 5. Compositional Nutrient Diagnosis norms for Rosa spp. grafted on $R$. × 'Natal Briar' obtained from a population with annual yields higher than 137 flowers $/ \mathrm{m}^{2}$.

\begin{tabular}{lrrr}
\hline Nutrient & Norm $\left(\mathrm{V}^{*}\right)^{\mathrm{z}}$ & $\mathrm{SD}^{\mathrm{z}}$ & $\mathrm{CV}(\%)^{\mathrm{z}}$ \\
\hline $\mathrm{N}$ & 3.35 & 0.18 & 5.3 \\
$\mathrm{P}$ & 0.73 & 0.21 & 28.8 \\
$\mathrm{~K}$ & 2.70 & 0.19 & 7.0 \\
$\mathrm{Ca}$ & 2.39 & 0.24 & 9.9 \\
$\mathrm{Mg}$ & 0.79 & 0.16 & 20.9 \\
$\mathrm{~S}$ & 1.04 & 0.20 & 19.2 \\
$\mathrm{Fe}$ & -2.75 & 0.23 & -8.4 \\
$\mathrm{Mn}$ & -2.39 & 0.49 & -20.5 \\
$\mathrm{Zn}$ & -3.30 & 0.45 & -13.8 \\
$\mathrm{Cu}$ & -5.17 & 0.44 & -8.5 \\
$\mathrm{~B}$ & -3.00 & 0.26 & -8.7 \\
$R^{\mathrm{y}}$ & 6.53 & 0.14 & 2.2 \\
\hline
\end{tabular}

${ }^{\mathrm{z}}\left(\mathrm{V}^{*}\right)=$ row-centered $\log$ ratios norms.

${ }^{\mathrm{y}} R=$ filling value, which includes nutrients not chemically analyzed.

It should be reiterated that a salient characteristic of the "Cultivars" data set is that it is composed with data from 39 rose cultivars grafted on $R . \times$ 'Natal Briar' and represents several greenhouse locations and soils and plants aged from 1 to 7 years. In practice, and as observed in other crops, this diversity ensures a broad applicability of the norms across the region, encompassing a wide range of cultivars, soils, plant ages, and environmental conditions (Hartz et al., 2007).

According to correlation coefficients $(r)$, the CND method could diagnose more accurately than DRIS nutrient imbalances affecting rose flower productivity, expressed in either flowers $/ \mathrm{m}^{2} /$ year $(-0.479$ vs. -0.432 ; Figs. $2 \mathrm{~A}$ and $2 \mathrm{C})$ or in relative terms $(-0.558$ vs. -0.532 ; Figs. 2B and 2D). Work in other crops has also shown enhanced nutrient diagnostic resolution with CND compared with DRIS procedures (Huang et al., 2012; Khiari et al., 2001b; Silva et al., 2004).

The use of relative flower productivities from the "Cultivars" data set allowed for a reduction in the variability given by the inherent genetic potential of each rose cultivar, which is independent of a plant nutrient status but produced enhanced correlations in both nutrient diagnostic methods (e.g., compare Fig. 2A vs. Fig. 2B and Fig. $2 \mathrm{C}$ vs. Fig. 2D). This supports the contention that 


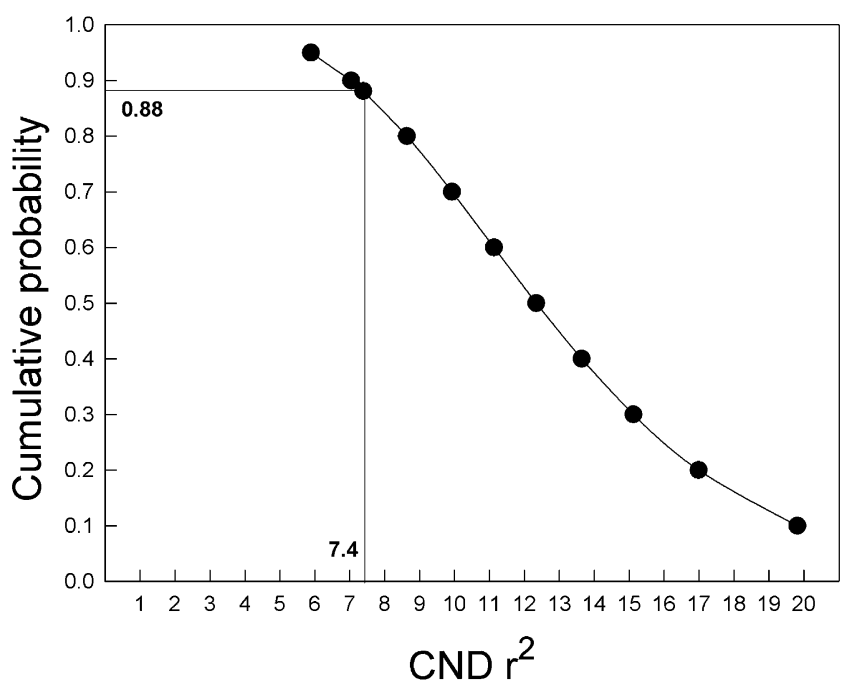

Fig. 1. $\chi^{2}$ probability function and theoretical value of the critical CND $r^{2}$ (CND nutrient imbalance index) in norms obtained for Rose spp. grafted on R. $\times$ 'Natal Briar'. CND $=$ Compositional Nutrient Diagnosis.
Table 6. Optimum ranges for the Compositional Nutrient Diagnosis (CND) $\left(I_{x}\right)$ indices, for each element, obtained from the 'Cultivar' validation data set. ${ }^{z}$

\begin{tabular}{lccc}
\hline & & \multicolumn{2}{c}{ CND I } \\
\cline { 3 - 4 } Nutrient & CND I $^{2}$ & Lower limit & Upper limit \\
\hline $\mathrm{N}$ & 0.57 & -0.76 & 0.76 \\
$\mathrm{P}$ & 1.01 & -1.00 & 1.00 \\
$\mathrm{~K}$ & 1.00 & -1.00 & 1.00 \\
$\mathrm{Ca}$ & 0.96 & -0.98 & 0.98 \\
$\mathrm{Mg}$ & 0.89 & -0.94 & 0.94 \\
$\mathrm{~S}$ & 0.96 & -0.98 & 0.98 \\
$\mathrm{Fe}$ & 1.03 & -1.01 & 1.01 \\
$\mathrm{Mn}$ & 0.99 & -1.00 & 1.00 \\
$\mathrm{Zn}$ & 1.02 & -1.01 & 1.01 \\
$\mathrm{Cu}$ & 1.01 & -1.00 & 1.00 \\
$\mathrm{~B}$ & 0.93 & -0.97 & 0.97 \\
$R^{\mathrm{y}}$ & 0.99 & -0.99 & 0.99 \\
$\mathrm{CND} r^{2}$ & & 0 & 7.10 \\
\hline
\end{tabular}

${ }^{2}$ The CND $r^{2}$ value is very similar to that obtained with a $\chi^{2}$ function (see Fig. 1) applied to the source data set.

${ }^{\mathrm{y}} R=$ filling value, which includes nutrients not chemically analyzed. when the potential impact of the plant genetics variable is diminished, the nutrient diagnosis method is likely to predict with more precision the expected productivity response, because this will then depend to a larger extent on environmental variables and production cultural practices, including crop fertilization (de Hoog, 2001). The use of relative flower and/or biomass yields has been previously used to establish critical leaf tissue chloride values in greenhouse roses (Cabrera and Perdomo, 2003) and salinity thresholds in garden roses and other horticultural and agronomic crops (Maas, 1990) using data sets that spanned over time and space scales.

The correlation coefficients between flower productivity and the DRIS and CND indices using data from the single rose cultivar, Charlotte (Fig. 3), were significant too $(P<$ $0.001)$ and higher than those observed when using several cultivars ("Cultivar" data set; Fig. 2), attesting to greater plant homogeneity in the former. Once again, the CND method produced higher correlations compared with DRIS and thus a greater capacity to explain the variability of rose flower productivity in terms of nutritional imbalances.

The data from the rose $\mathrm{N}$ nutrition study ("Nitrogen" data set) produced the highest validation correlations between relative flower productivity and the DRIS and CND balance indices for $\mathrm{N}\left(\mathrm{I}_{\mathrm{N}}\right.$; Fig. 4B-C), emulating the high correlations that had been previously obtained with the elemental leaf $\mathrm{N}$ concentrations (Fig. 4A; Cabrera, 2000). This result is attributed to the use of very controlled crop management practices used in that research study, which included a climate-controlled greenhouse, a homogeneous soilless substrate (peat-based), and a tightly regulated and monitored fertigation program. Furthermore, the validation of DRIS and CND norms generated in the present study with this "Nitrogen" data set is of utmost significance, because the climatic and growing conditions
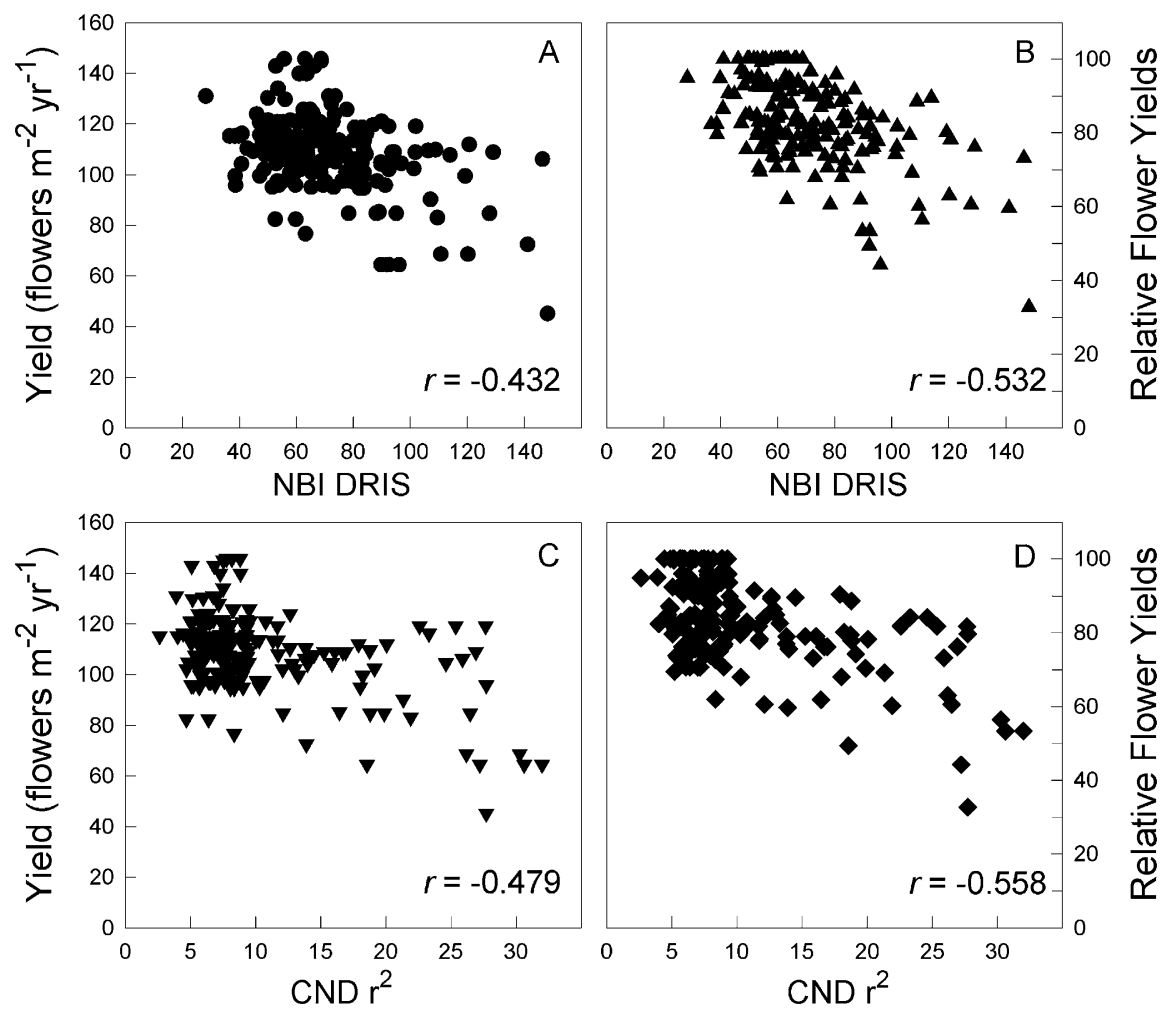

Fig. 2. Correlations between absolute and relative flower productivities and the DRIS (A-B) and CND (C-D) balance indices for a population conformed by plants of 39 rose cultivars grafted on $R$. × 'Natal Briar'. $P<0.001$ and $\mathrm{n}=191$. DRIS $=$ Diagnosis and Recommendation Integrated System; $\mathrm{CND}=$ Compositional Nutrient Diagnosis; NBI $=$ Nutrient Balance Index; $\mathrm{CND} r^{2}=\mathrm{CND}$ nutrient imbalance index.

(California), rootstock used ( $R . \times$ 'Manetti'), and the sampled leaf age (younger) were significantly different from those evaluated in Colombia. We therefore propose that the DRIS and CND norms generated in the present study could be satisfactorily used in other settings and rose crop management practices and conditions, most certainly providing a very good starting point or reference when lacking local nutrient diagnostic criteria or norms.
In summary, the DRIS and CND norms obtained for roses (on $R . \times$ 'Natal Briar') growing under the production conditions in the Bogotá Plateau can be used successfully in the identification of nutrient imbalances that can significantly affect cut flower yields and provide for potential improvements in fertilization management and efficiency across multiple cultivars and plant (crop) ages. Furthermore, it was preliminarily (i.e., theoretically) 


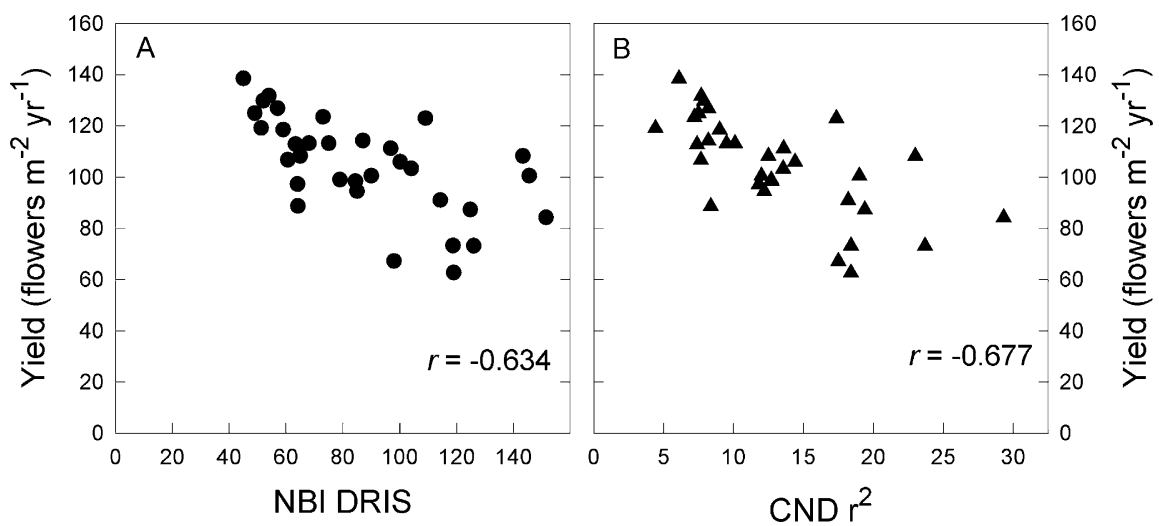

Fig. 3. Correlations between flower productivity and DRIS (A) and CND (B) balance indices for a population conformed by plants of a single rose cultivar, Charlotte, grafted on $R . \times$ 'Natal Briar'. $P<$ 0.001 and $\mathrm{n}=33$. DRIS $=$ Diagnosis and Recommendation Integrated System; $\mathrm{CND}=$ Compositional Nutrient Diagnosis; NBI $=$ Nutrient Balance Index; CND $r^{2}=$ CND nutrient balance index.

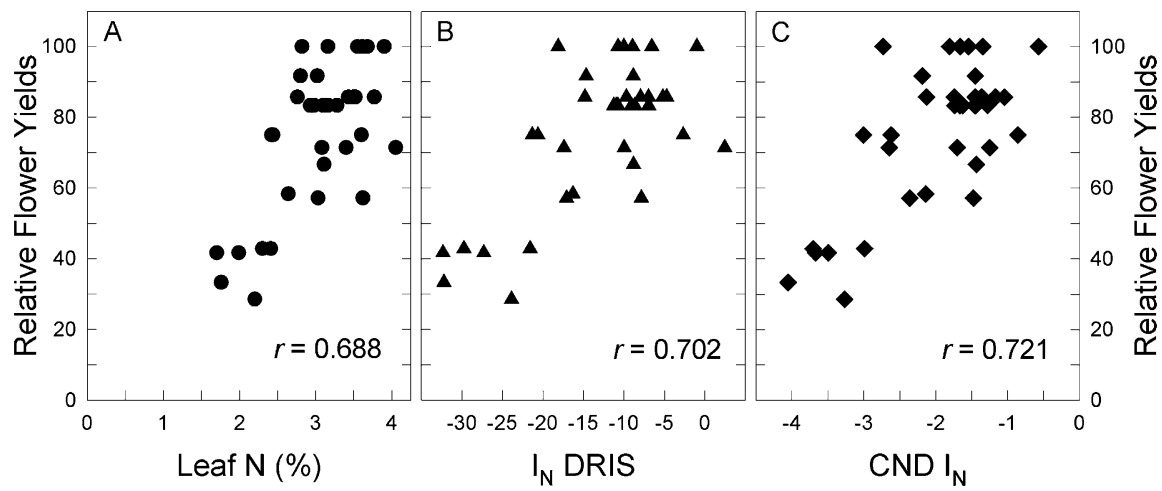

Fig. 4. Correlations between relative flower productivity from 'Royalty' roses grafted on $R . \times$ 'Manetti' and leaf nitrogen concentration (A) and the balance indices for nitrogen $\mathrm{I}_{\mathrm{N}}$ DRIS (B) and CND I $\mathrm{I}_{\mathrm{N}}(\mathbf{C})$ generated from the validation data set "Nitrogen" (Cabrera, 2000). $P<0.001$ and $\mathrm{n}=36$. DRIS $=$ Diagnosis and Recommendation Integrated System; $\mathrm{CND}=$ Compositional Nutrient Diagnosis.

established that the use of these diagnostic norms could be extended to rose crops growing under other, different rootstocks, environmental and production conditions, and management. An analysis of information provided by these two procedures (DRIS and CND) indicated that relations associated with $\mathrm{N}, \mathrm{P}$, $\mathrm{Mg}, \mathrm{Mn}$, and $\mathrm{B}$ had very significant effects on the nutritional balance and productivity of roses growing under the conditions of this Colombian region. The practical applicability of these nutrient diagnostic norms is being experimentally tested to fine-tune fertilization recommendations and practices to correct rose crop imbalances and disorders associated with these nutrients. An added benefit from the correction and optimization of fertilization practices through the use of these integrative nutrient diagnostic procedures is the potential for reductions in both fertilizer use (cost savings) and its environmental impacts (leaching and runoff losses).

\section{Literature Cited}

Arboleda, C., J. Arcila, and R. Martínez. 1988. Sistema integrado de recomendación y diagnosis: Una alternativa para la interpretación de resultados del análisis foliar en café. Agronomía Colombiana 5:17-30.
Asocolflores. 2012. Colombian floriculture 2010. Asociación Colombiana de Exportadores de Flores (Asocolflores). 26 June 2012. <http:// www.asocolflores.org>.

Beaufils, E.R. 1973. Diagnosis and Recommendation Integrated System, DRIS. A general scheme of experimentation and calibration based on principles developed from research in plant nutrition. Soil Sci. Bull 1:1-132.

Cabrera, R.I. 2000. Evaluating yield and quality of roses with respect to nitrogen fertilization and leaf tissue nitrogen status. Acta Hort. 511:133141. tioning and nutrient status responses to rootstock selection. Sci. Hort. 95:75-83.

Cabrera, R.I. 2003. Mineral nutrition, p. 573-580. In: Gudin, R.S. and T. Debener (eds.). Encyclopedia of rose science. Academic Press, London, UK.

Cabrera, R.I. 2006. Consideraciones sobre nutrición mineral y fertilización en rosas, p. 145162. In: Flórez, V., A. Fernández, D. Miranda, B. Chávez, and M. Guzmán (eds.). Avances sobre Fertirriego en la Floricultura Colombiana. Unibiblos, Bogotá, Colombia.

Cabrera, R.I. and P. Perdomo. 2003. Reassessing the salinity tolerance of greenhouse roses. HortScience 38:533-536.

de Hoog, J. 2001. Handbook for modern greenhouse rose cultivation. Applied Plant Research, Aalsmeer, The Netherlands.
Cabrera, R.I. 2002. Rose yield, dry matter parti-
Fageria, V. 2001. Nutrient interactions in crops plants. J. Plant Nutr. 24:1269-1290.

García, J., R. Valdéz, N. Avila, B. Murillo, A. Nieto, R. Magallanes, J. Larrinaga, and E. Troyo. 2005. Preliminary compositional nutrient diagnosis norms for cowpea grown on desert calcareous soil. Plant Soil 271:297-307.

García, J., R. Valdez, B. Murillo, F. Beltrán, F. Ruiz, I. Orona, A. Flores, and E. Troyo. 2006. Preliminary compositional nutrient diagnosis norms in Aloe vera L. grown on calcareous soil in an arid environment. Environ. Exp. Bot. 58:244-252.

Guzmán, M. and A. Sánchez. 2003. Influence of nitrate and calcium increments on development, growth and early yield in sweet pepper plants. Acta Hort. 609:207-211.

Hartz, T.K., P.R. Johnstone, E. Williams, and R.F Smith. 2007. Establishing lettuce leaf nutrient optimum ranges through DRIS analysis. HortScience 42:143-146.

Huang, H., C.X. Hu, Q. Tan, X. Hu, X. Sun, and L. Bi. 2012. Effects of Fe-EDDHA application on iron chlorosis of citrus trees and comparison of evaluations on nutrient balance with three approaches. Sci. Hort. 146:137-142.

Instituto Geográfico Agustín Codazzi. 1990. Métodos Analíticos del Laboratorio de Suelos, $5^{\text {a }}$ Edición. Instituto Geográfico Agustín Codazzi, Bogotá, Colombia.

Instituto Geográfico Agustín Codazzi. 2000. Estudio General de Suelos y Zonificación de Tierras del Departamento de Cundinamarca. Tomo II. Instituto Geográfico Agustín Codazzi, Bogotá, Colombia

Jones, C.A. 1981. Proposed modifications of the Diagnosis and Recommendation Integrated System for interpreting plant analyses. Commun. Soil Sci. Plant Anal. 12:785-794.

Khiari, L., L.E. Parent, and N. Tremblay. 2001a. Selecting the high-yield subpopulation for diagnosing nutrient imbalance in crops. Agron. J. 93:802-808.

Khiari, L., L.E. Parent, and N. Tremblay. 2001b. The phosphorus compositional nutrient diagnosis range for potato. Agron. J. 93:815-819.

Khiari, L., L.E. Parent, and N. Tremblay. 2001c. Critical compositional nutrient indexes for sweet corn at early growth stage. Agron. J. 93:809-814.

Lucena, J.J. 1997. Methods of diagnosis of mineral nutrition of plants: A critical review. Acta Hort. 448:179-192.

Maas, E.V. 1990. Crop salt tolerance, p. 262-304. In: Tanji, K.K. (ed.). Agricultural salinity assessment and management. ASCE Manuals and Reports on Engineering Practice No. 71 Amer. Soc. of Civil Engineers, New York, NY.

Magallanes, R., R. Valdez, F. Blanco, B. Murillo, J. García, R. Ruiz, M. Márquez, and F. Macías. 2004. Compositional Nutrient Diagnosis in nopal. J. Prof. Assoc. Cactus Development. 6:78-89.

Magallanes, R., R. Valdez, E. Olivares, O. Pérez, J. García, and J. López. 2006. Compositional Nutrient Diagnosis in maize grown in a calcareous soil. J. Plant Nutr. 29:2019-2035.

Martín, I., M. Prieto, M. López, N. Alonso, C. Cadahía, and E.A. Eymar. 2007. Preliminary norms for DRIS to fertigate ornamental shrubs. J. Plant Nutr. 30:21-35.

Marschner, H. 1995. Mineral nutrition of higher plants. 2nd Ed. Academic Press, London, UK.

Merhaut, D.J. 2007. Magnesium, p. 145-181. In: Barker, A.V. and D.J. Pilbeam (eds.). Handbook of plant nutrition. CRC Press, Boca Raton, FL.

Mills, H. and J. Jones. 1996. Plant analysis handbook II: A practical sampling, preparation, 
analysis and interpretation guide. MacroMicro Publishing, Inc., Athens, GA.

Mourão, F. 2004. DRIS: Concepts and applications on nutritional diagnosis in fruit crops. Sci. Agric. 61:550-560.

Mourão, F. and J.C. Azevedo. 2003. DRIS norms for 'Valencia' sweet orange on three rootstocks. Pesquisa Agropecu. Bras. 38:85-93.

Nelson, L. and R. Anderson. 1977Partitioning of soil test-crop response probability, p. 19-38. In: Soil testing: Correlating and interpreting the analytical results. Am. Soc. Agron. Special Publication No. 29.

Ortega, D. 1997. Fertirrigación en cultivos de flores, p. 136-147. In: Silva, F. (ed.). Fertirrigación. Sociedad Colombiana Ciencia del Suelo, Bogotá, Colombia.
Parent, L. and M. Dafir. 1992. A theoretical concept of compositional nutrient diagnosis. J. Amer. Soc. Hort. Sci. 117:239-242.

Ramos-Miras, J.J., L. Roca-Perez, M. GuzmánPalomino, R. Boluda, and C. Gil. 2011. Background levels and baseline values of available heavy metals in Mediterranean greenhouse soils (Spain). J. Geochem. Explor. 110:186192.

Reis, J.R.A. and P.H. Monnerat. 2003. Norms establishment of the Diagnosis and Recommendation Integrated System (DRIS) for nutritional diagnosis of sugarcane. Pesquisa Agropecu. Bras. 38:277-282.

Ruíz, A. and L. Cajuste. 2002. Controlling fertilizer applications through plant analysis. Commun. Soil Sci. Plant Anal. 33:2793-2802.
Silva, G., J. Neves, V. Alvarez, and F. Leite. 2004 Nutritional diagnosis for eucalypt by DRIS, M-DRIS and CND. Sci. Agr. 61:507-515.

Sumner, M. 1979. Interpretation of foliar analysis for diagnostic purposes. Agron. J. 71:343348.

Wadt, P. 1999. DRIS: Nuevos conceptos para aplicación en árboles de eucalipto. Piracicaba $1: 1-15$.

Walworth, J.L. and M. Sumner. 1987. The Diagnosis and Recommendation Integrated System (DRIS), p. 149-188. In: Stewart, B.A. (ed.). Advances in soil science. Vol. 6. SpringerVerlag, New York, NY.

White, J.W. 1987. Fertilization, p. 87-135. In: Langhans, R.W. (ed.). Roses. Roses Incorporated, Haslett, MI. 